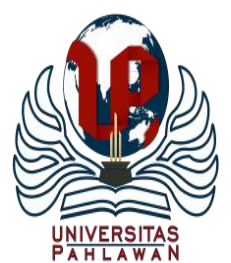

Edukatif : Jurnal Ilmu Pendidikan Volume 3 Nomor 1 Tahun 2021 Halm 124-134

EDUKATIF: JURNAL ILMU PENDIDIKAN

Research \& Learning in Education

https:/ledukatif.org/index.php/edukatif/index

\title{
Analisis terhadap Perhatian dan Belajar Perseptual dalam Aktivitas Belajar Siswa
}

\author{
Ilham Wahyudi ${ }^{1 凶}$, Neviyarni $^{2}$ \\ Universitas Negeri Padang, Sumatera Barat, Indonesia ${ }^{1,2}$ \\ E-mail : wahyudi.ilham066@gmail.com ${ }^{1} \underline{\text { neviyarni.suhaili911@gmail.com }}^{2}$
}

\begin{abstract}
Abstrak
Artikel ini bertujuan untuk menganalisis terhadap perhatian dan belajar perseptual dalam aktivitas belajar pada siswa, metode yang digunakan adalah dengan kajian literatur kepustakaan yang relevan dalam mengembangkan dan menganalisis terkait dengan perhatian dan belajar perseptual dalam aktivitas belajar siswa, perhatian dan belajar perseptual berperan dalam membentuk pola perilaku siswa dalam menerima pembelajaran, dimana perhatian dan belajar perseptual merupakan bentuk sarana pendukung individu dalam menerima dan memproses rangsangan stimulus yang diberikan guru ketika pembelajaran berlangsung. Perhatian dan belajar perseptual dalam aktivitas belajar siswa merupakan sebuah metode pembelajaran yang dapat mendukung proses belajar mengajar agar efektif dan merupakan langkah dalam mencapai tujuan pembelajaran.
\end{abstract}

Kata kunci: perhatian, belajar perseptual, aktivitas belajar

\begin{abstract}
This article aims to analyze attention and perceptual learning in student learning activities. the method used is the study of relevant literature in developing and analyzing related perceptual attention and learning in student learning activities. Attention and perceptual learning play a role in shaping patterns. Student behavior in receiving learning, where perceptual attention and learning is a form of means of supporting individuals in receiving and processing stimulus stimuli given by the teacher when learning takes place. Attention and perceptual learning in student learning activities is a learning method that can support the teaching and learning process to be effective and is a step in achieving learning objectives.
\end{abstract}

Keywords: attention, perceptual learning, learning activities

Copyright (c) 2021 Ilham Wahyudi, Neviyarni

$\triangle$ Corresponding author

Email : wahyudi.ilham066@gmail.com

DOI : https://doi.org/10.31004/edukatif.v3i1.231

ISSN 2656-8063 (Media Cetak)

ISSN 2656-8071 (Media Online) 
125 Analisis terhadap Perhatian dan Belajar Perseptual dalam Aktivitas Belajar Siswa - Ilham Wahyudi, Neviyarni

DOI : https://doi.org/10.31004/edukatif.v3i1.231

\section{PENDAHULUAN}

Manusia merupakan makhluk ciptaan Tuhan yang diberikan keistimewaan untuk memahami situasi yang ada pada lingkungannya, dalam menangkap informasi yang ada manusia menggunakan alat indranya (telinga, mata, hidung, dan lain-lain), manusia tentu saja memiliki keterbatasan dalam menerima infomasi yang didapat dari lingkungannya seperti melakukan sebuah interaksi dengan seseorang manusia hanya bisa berbicara dengan satu orang, apabila memaksakan pembicaraan dengan dua orang atau lebih, maka siap-siap untuk menerima situasi dimana kita tidak memahami dengan baik informasi yang ada.

Dalam keterbatasan manusia memahami infomasi yang diterima karena banyaknya stimulus yang datang secara bersamaan, sehingga informasi terkait yang dibutuhkan tidak dapat dipahami dengan jelas, hal tersebut merupakan bentuk keterbatasan manusia menerima informasi yang melebihi kapasitas perhatian (attention capacity) yang merupakan kapasitas maksimum dalam mendengarkan serta memproses informasi, sehingga apabila kapasitas tersebut terlewati, maka informasi yang diterima atau yang datang akan ambigu bahkan hilang.

Informasi merupakan sebuah bentuk stimulus dari luar individu, dimana dalam menerima informasi membutuhkan perhatian sebagai upaya dalam menerima infromasi secara baik sehingga informasi yang diterima dapat diolah secara maksimal dengan langkah awal yaitu perhatian. Perhatian merupakan sebuah upaya untuk memusatkan tenaga atau kekuatan jiwa terhadap objek yang dituju. Perhatian juga diartikan sebagai sebuah pendayagunaan terhadap kesadaran yang disertakan dengan aktivitas yang dilakukan (menurut Stern; dalam Syaiful Sagala, 2012: 130).

Dalam sebuah aktivitas proses belajar dan mengajar, pemilihan bentuk jenis perhatian yang efektif diperlukan dalam menunjang aktivitas belajar, dimana untuk memperoleh dari tujuan aktivitas tersebut dibutuhkan metode atau cara yang efektif dalam memperoleh pengalaman belajar, dimana bagi siswa pengalaman belajar yang baik memberikan efektivitas yang cenderung positif terhadap penerimaan rangsangan stimulus yang diberikan oleh tenaga pengajar kepada siswa, sehingga menarik perhatian siswa dalam belajar.

Dalam proses belajar mengajar perhatian siswa dipengaruhi oleh beberapa faktor, faktor tersebut berasal dari dalam diri siswa dan dari luar diri siswa, sebuah stimulus yang berbeda akan menimbulan perhatian dan persepsi tersendiri bagi siswa, dimana hal tersebut memberikan sebuah rangsangan atau respon yang berbeda juga bagi masing-masing siswa terkait dengan stimulus yang datang dari tenaga pengajar atau guru. Sebuah stimulus yang menjemukan dan membosankan bagi siswa tidak akan memberikan daya tarik bagi siswa dan siswa cenderung untuk mengalihkan perhatiannya kepada hal lain. Sehingga siswa tidak akan mampu berkonsentrasi dan belajar dengan sungguh-sungguh.

Dalam belajar siswa cendrung memiliki persepsi yang berbeda ketika menangkap stimulus yang datang, seperti halnya perhatian persepsi mempunyai perannya sendiri dalam memaknai stimulus terhadap infomasi yang ditangkap, baik dari lingkungannya maupun dari informasi yang diberikan guru ketika proses belajar mengajar.

Pembelajaran perseptual adalah merupakan sebuah usaha yang dilakukan secara sengaja yang mengacu kepada berbagai perubahan terhadap persepsi yang dihasilkan ketika dalam proses pembelajaran (menurut Henry C Ellis, 1978:207).

Dalam proses pembelajaran, persepsi berperan penting dalam menentukan pengolahan informasi yang dilakukan ketika proses belajar mengajar, dimana ketika menangkap informasi yang diberikan oleh guru persepsi memberikan sebuah respon terhadap rangsangan stimulus yang didapat pada saat proses belajar mengajar. 
126 Analisis terhadap Perhatian dan Belajar Perseptual dalam Aktivitas Belajar Siswa - Ilham Wahyudi, Neviyarni

DOI : https://doi.org/10.31004/edukatif.v3i1.231

Peran guru sangat penting untuk dapat membangkitkan perhatian siswa maupun dalam menumbuhkan persepsi yang positif ketika proses pembelajaran dengan menggunakan metode dan berbagai strategi yang hendaknya mampu membangkitkan perhatian siswa sehingga aktivitas belajar pada siswa dapat berjalan optimal.

Dengan adanya perhatian yang dimiliki oleh siswa, hal tersebut akan membantu proses pembelajaran siswa dalam memilih stimulus-stimulus yang masuk ke dalam otak. Perhatian berhubungan langsung dengan aspek kognitif siswa, sehingga siswa akan mudah berpikir dan mudah dalam menerima pelajaran dari guru. Sehingga fungsi perhatian dalam proses pembelajaran sangat penting untuk meningkatkan aktivitas belajar siswa.

Aktivitas belajar pada siswa berjalan dengan baik apabila diringi dengan perhatian dan persepsi yang baik terhadap rangsangan stimulus yang diberikan guru. Perhatian mencakup kepada keaktifan jiwa yang di arahkan kepada proses pembelajaran, dimana dalam perhatian siswa akan cendrung melakukan aktivitas belajar dengan penuh kesadaran dan keseriusan dalam mencapai tujuan belajar.

Perhatian siswa merupakan keaktifan jiwa yang diarahkan kepada suatu proses pembelajaran atau aktivitas belajar. Siswa yang mempunyai perhatian tinggi dalam proses pembelajaran akan cenderung bersikap melakukan aktivitas belajar dengan penuh kesadaran dan keseriusan dalam mencapai prestasi belajar yang tinggi.

Aktivitas proses pembelajaran meningkat diperlukan perhatian dan belajar perseptual dalam meningkatkan aktivitas belajar pada siswa, maka dari itu, penulis bermaksud akan melakukan kajian teoritis dalam bentuk analisis terhadap perhatian dan belajar perseptual dalam aktivitas belajar pada siswa.

\section{METODE PENELITIAN}

Artikel ini bertujuan untuk menganalisis terhadap perhatian dan belajar perseptual dalam aktivitas belajar siswa. Jenis metode penelitian ini adalah analisis kajian pustaka (literatur research. Artikel ini akan memaparkan analisis jurnal ilmiah yang relevan dengan pembahasan yang sudah dipilih. Adapun tahap- tahap dalam metode penelitian ini adalah (1) memilih artikel, (2) mengumpulkan data awal, (3) tantangan dari topik,(4) mengumpulkan data pendukung, (5) menghasilkan kesimpulan dan rekomendasi online.

\section{HASIL DAN PEMBAHASAN PENELITIAN}

\section{A. Dikotik Pendengaran dan Perhatian.}

Penelitian tentang kapasitas perhatian seseorang sering dikaitkan dengan tugas yang cenderung saling mempengaruhi satu sama lain. Salah satu dari penelitian tersebut adalah penelitian tentang tugas pendengaran dikotik (dichotic listening task) atau tugas pendengaran terpisah. Dalam penelitian ini, pesan primer (primary massage) diberikan kepada salah satu telinga dan berisi informasi yang terstruktur.

Untuk mengetahui apakah subjek penelitian benar-benar mendengar informasi tersebut, mereka diinstruksikan untuk membayangkan (to shadow) pesan primer tersebut dengan cara mengulang setiap kata sesegera mungkin setelah ia mendengarkannya. Pesan sekunder (secondary massage) diberikan ketelinga yang satu lagi dalam jarak satu menit. Subjek penelitian diminta untuk membayangkan pesan primer secepat dan seakurat mungkin.

Gangguan perhatian diukur dengan cara membandingkan kecepatan dan ketepatan penyajian pembayangan, ketika ia diminta melakukan pembayangan (shadowing) terpisah dengan pembayangan yang dilakukan serentak pada saat kedua tugas digabungkan. Jika subjek melakukan pembayangan tidak sempurna 
127 Analisis terhadap Perhatian dan Belajar Perseptual dalam Aktivitas Belajar Siswa - Ilham Wahyudi, Neviyarni

DOI : https://doi.org/10.31004/edukatif.v3i1.231

mereka diminta menekan tombol sinyal, dan kita dapat menafsirkan bahwa pada saat itu mereka memerlukan perhatian yaang lebih besar dari pada kapasitas perhatian yang ada (Henry C Ellis, 1978 : 203).

Variabel yang banyak menarik perhatian pakar dalam hal ini adalah keterkaitan antara pesan primer dengan pesan sekunder. Sebuah penelitian membuktikan bahwa jika subjek penelitian melakukan shadowing sebuah wacana prosa, pesan sekunder cenderung berupa: (1) wacana prosa yang agak sama, (2) wacana prosa lain yang agak mirip, dan (3) sesuatu yang tidak berkaitan dalam bahasa Inggris. Ada indikasi bahwa subjek penelitian hanya memperhatikan suatu aspek saja dari pesan, jika wacana prosa yang sama diberikan ke kedua belah telinga, subjek memperhatikan hanya perubahan dalam pesan sekunder saja, jika suara berubah dari pria ke wanita.

Donal MacKay melakukan penelitian tentang pengaruh pesan sekunder terhadap pesan primer dan ia membaginya dalam tiga tingkatan, yaitu (dalam Henry C Ellis, 1978 : 204):

1. Tingkat Leksikal. Umpanya, ia menggunakan kata bank, yang bisa bermakna tempat menyimpan uang atau tebing sungai. Isi pesan primer dipengaruhi oleh isi pesan sekunder, karena adanya kata yang berbunyi sama. MacKay menyimpulkan bahwa kata dalam pesan sekunder mempengaruhi penafsiran kalimat dalam pesan primer.

2. Tingkat Struktur Permukaan (Surface Stucture). Bahwa kapasitas perhatian tidak melebihi kapasitas yang ada, bila subjek memproses sebuah kalimat dan struktur permukaan sekunder bersamaan dengan pesan primer.

3. Tingkat Struktur Dalam. Pesan sekunder tidak mempunyai pengaruh terhadap penafsiran pesan primer.

Sarlito W. Sarwono (2009 : 103), pada setiap saat ada ratusan, mungkin ribuan rangsangan yang tertangkap oleh semua indra kita. Tentunya, kita tidak mampu menyerap seluruh rangsangan yang ada di sekitar kita sekaligus. Dengan keterbatasan daya serap, persepsi yang ada pada manusia memaksa kita hanya untuk fokus pada satu perhatian atau memusatkan konsentrasi pada satu stimulus rangsangan informasi yang diberikan pada satu objek (Menurut Bimo Walgito, 2010: 110). Perhatian adalah sebuah pemusatan atau mengkondisikan diri untuk konsentrasi dari aktivitas individu yang ditujukan pada suatu objek atau sekumpulan objek tertentu. Selanjutnya menurut Abu Ahmadi (2003 : 145), perhatian mempunyai hubungan yang erat terkait dengan kesadaran jiwa terhadap suatu objek yang direaksi pada suatu waktu. Terang tidaknya kesadaran kita terhadap sesuatu objek tertentu tidak tetap, ada kalanya kesadaran kita meningkat kesadaran kita meningkat (menjadi terang) dan ada kalanya menurun (menjadi samar-samar). Dalam lingkungan kesadaran dan tingkat perhatian bersifat fleksibel dan berubah-ubah, kadang bisa menjadi luas bahkan bisa menjadi sempit. Hal tersebut tergantung dari pengerahan terhadap aktivitas jiwa pada objek yang dituju.

Dalam taraf kesadaran, manusia mempunyai konsep bahwa kesadaran manusia akan meningkat jika jiwa mereaksi lingkungan dengan cara meningkat juga. Apabila taraf persentase kekuatan kesadaran manusia naik atau bahkan menjadi lebih karena sesuatu hal yang menyebabkan tersebut, maka manusia akan berada pada tahap permulaan dalam perhatian. Perhatian akan timbul dengan adanya pemusatan kesadaran manusia terhadap objek yang dituju.

Manusia menaruh perhatian terhadap lingkungannya, dimana perhatian yang dimaksud adalah sebuah kegiatan yang dilakukan oleh seseorang terkait dengan pemilihan stimulus terhadap rangsangan yang datang dari lingkungannya (Daryanto, 2010 : 108). Jika seseorang sedang berjalan di sebuah jalan besar, maka ia cenderung sadar akan adanya lalu lintas yang ada di sekelilingnya, dengan kendaraan-kendaraan bahkan orang-orang yang lewat, serta toko-toko yang ada di tepi jalan. Dalam keadaan tersebut, kita tidak dapat mengatakan orang tersebut menaruh perhatiannya terhadap lingkungannya, bahkan tertarik akan hal-hal yang ada di sekelilingnya. 
128 Analisis terhadap Perhatian dan Belajar Perseptual dalam Aktivitas Belajar Siswa - Ilham Wahyudi, Neviyarni

DOI : https://doi.org/10.31004/edukatif.v3i1.231

Tetapi, jika kemudian kita lihat ia bertemu seseorang yang dikenalnya dan kemudian bercakap-cakap dengannya, maka kita dapat mengatakan bahwa orang tersebut berada dalam keadaan sedang memperhatikan, yaitu ia mengarahkan indra atau sistem persepsinya untuk menerima informasi tentang sesuatu, dalam hal ini tentang orang yang dikenalnya itu, dalam tingkat yang lebih terinci. Tingkat yang lebih tinggi dari menaruh perhatian adalah menaruh minat. Orang tidak lagi hanya bersedia untuk mendengarkan sesuatu, misalnya, tetapi ia juga bersedia untuk memberi tanggapan mengenai apa yang didengarnya. Guru sebagai tenaga pengajar mempunyai masalah yang harus disikapi dengan bijak, yaitu bagaimana guru menarik perhatian siswa dan bagaimana usaha yang maksimal dalam menjaga perhatian siswa tersebut agar tetap berjalan dengan seharusnya.

Dalam perhatian, siswa dituntut untuk fokus menangkap stimulus atau informasi yang diberikan oleh lingkungannya, lingkungan yang dimaksud tentunya dalam konteks sekolah atau dalam proses belajar mengajar di kelas, terkait dengan perhatian terdapat beberapa prinsip, dimana kondisi perhatian yang ada pada siswa dapat tertuju atau bahkan diarahkan terhadap hal-hal yang baru, suatu hal yang baru serta diperoleh dengan pengalaman yang baru, tentu saja memiliki nilai yang bermakna dalam hidup manusia. Jika seorang siswa sedang membaca buku, apa yang belum pernah ia baca secara relatif merupakan hal yang baru dibanding dengan buku yang pernah ia baca dan karenanya, buku yang belum pernah dibacanya itu akan menarik perhatiannya. Jenis rangsangan baru yang dapat menarik perhatian termasuk warna dan bentuk. Dalam sebuah proses pembelajaran, seorang tenaga pengajar atau guru dapat menarik perhatian siswa dengan cara membuat sebuah mind mapping yang menarik disertai dengan kata-kata penting dalam sebuah bacaan dengan memberikan warna yang berbeda pada tulisan penting yang dimaksud seperti mewarnainya dengan warna merah atau dengan meberikan garis bewarna pada di bawah kata-kata tersebut, hal yang sama juga dapat dilakukan pada usaha untuk memberi bentuk yang lebih besar pada bagian tubuh gambar seseorang yang perlu diperhatikan, misalnya dalam gambar ataupun karikatur.

\section{B. Teori-Teori Perhatian}

Henry C Ellis (1978 : 205) menjelaskan bahwa teori-teori perhatian sebagai berikut:

1. Teori Filter (Filter Theory). Teori filter dikembangkan oleh ahli psikologis Inggris Donald Broodbent. Ia mengajukan sebuah sistem pengolahan informasi yang dianggap sebagai sebuah saluran berbentuk huruf Y. Lengan Y merupakan saluran input pengindraan, dan cabangnya merupakan bagian sistem yang berkapasitas terbatas. Tempat saluran pengindraan merupakan sebuah lempengan yang dapat pindah-pindah ke salah satu arah saluran dan pada saat itu menutup saluran yang lain. Bila informasi masuk melalui sebuah saluran, saluran yang lainnya selalu tertutup untuk informasi yang sama, jadi saluran tersebut berupa all or none, dalam arti bahwa informasi mengambil semua saluran sistem atau disaring seluruhnya pada tingkat pengindraan. Menurut teori Broadbent, ini saluran pengindraan diasumsikan berhubungan dengan karakteristik fisik stimulus yang datang. Jadi, satu saluran untuk frekuensi tinggi dan saluran lain untuk frekuensi rendah. Dalam teori Broadbent juga menyatakan bahwa dalam pesan sekunder tidak disaring pada tingkat pengindraan dalam menangkap sebuah stimulus atau infomasi yang masuk.

2. Teori saringan yang disusutkan/mengecil (Attenuated Filter Theory). Teori ini dikembangkan untuk mengatasi kelemahan pada teori pertama dalam hal kesulitan mendapatkan saring all-or-none. Teori ini menyatakan bahwa saringan perseptual tidak bertindak di dalam bentuk all-in-none, tetapi ia berperan mengurangi atau menurunkan jumlah informasi yang masuk ke dalam saluran sekunder. Teori ini lebih jauh berasumsi bahwa jumlah penurunan pesan sekunder tersebut terjadi pada saat jumlah saluran yang membawa informasi meningkat. Jadi, pada teori ini dapat dikatakan bahwa ketika saluran pengindraan 
129 Analisis terhadap Perhatian dan Belajar Perseptual dalam Aktivitas Belajar Siswa - Ilham Wahyudi, Neviyarni

DOI : https://doi.org/10.31004/edukatif.v3i1.231

menerima informasi terhadap stimulus yang masuk lebih banyak maka keefektifan dari saringan infromasi dalam memblok pengindraan yang kurang relevan dapat berkurang. Perbedaan teori ini dari teori McKay adalah bahwa teori McKay beranggapan bahwa pesan sekunder disaring, sedangkan attenuated filter theory beranggapan bahwa pesan sekunder tidak disaring.

3. Teori Tanpa Penyaringan Pengindraan (No Sensory Filter Theory).Teori ini beranggapan bahwa semua stimulus diasumsikan melakukan kontak dengan representasinya di dalam memori, yang menghasilkan pengaktifan representasi tersebut. Jadi tidak ada batas jumlah stimulus yang dapat berhubungan dengan memori. Keterbatasan terdapat pada saat pemrosesan yang terjadi setelah adanya kontak memori dengan beberapa jenis proses berikutnya yang memerlukan perhatian yang lebih besar. Stimulus dipilih untuk melakukan pemrosesan lebih lanjut berdasarkan pada tingkat pentingnya stimulus tersebut bagi orang bersangkutan. Sementara tingkat pentingnya stimulus yang masuk tersebut ditentukan berdasarkan pengalaman masa lalu dan beberapa faktor lain. Sehingga nama kita sendiri merupakan stimulus yang dianggap penting bagi kita dan akan diproses lebih lanjut setelah ia berhubungan dengan memori.

\section{Belajar Perseptual}

Menurut Henry C Ellis (1978 : 207), pembelajaran perseptual secara umum mengacu kepada berbagai perubahan didalam persepsi yang dapat dihasilkan oleh proses pembelajaran. Contoh dari pembelajaran perseptual ini adalah mengingat suatu irama lagu, walaupun lagu tersebut dimainkan oleh orang yang berbeda dengan menggunakan instrumen yang berbeda. Kenyataan bahwa kita dapat mengetahui serangkaian bentuk (dalam hal ini irama lagu) walaupun lagu tersebut sudah mengalami perubahan besar di dalam konteks musik merupakan sebuah contoh proses yang disebut dengan pembelajaran konseptual (conceptual learning). Contoh lain dari proses pembelajaran perseptual adalah pada saat kita melakukan mengidentifikasi objek secara cermat dan tepat di bawah mikroskop. Pada saat memulainya memang sulit bagi kita membedakan objekobjek yang banyak dibawah mikroskop tersebut, tetapi pada saat kita terlatih kita dengan cepat dan mudah bisa membedakan objek yang diperhatikan dengan objek yang tidak relevan. Jadi, pembelajaran perseptuaal akan menjadi baik dengan menerapkan banyak latihan.

Penelusuran dan pencarian sesuatu dengan cepat (scanning) merupakan suatu jenis situasi pembelajaran perseptual. Pada saat penelusuran dan scanning tersebut, kita dapat membedakan berbagai respon secara cepat. Umpamanya, pada saat kita mencari seseorang ditengah kerumunan orang banyak, kita mencari sebuah mobil di antara banyak mobil yang sedang parkir, kita mencari sebuah lokasi dalam peta, dan lain-lain. Semua kegiatan tersebut dilakukan secara terampil dan cepat. Kecakapan kecepatan mencari dan scanning kita dapat tingkatkan, dan ini merupakan bukti bahwa pada saat itu kita melakukan pembelajaran.

Jika sebuah stimulus diasosiasikan dengan respon tertentu, stimulus pada saat tersebut harus dapat ditangkap di dalam bentuk yang relatif konsisten dari latihan ke latihan berikutnya. Proses tersebut disebut dengan perhatian (attention) terhadap signifikansi proses perseptual di dalam pembelajaran asosiatif. Namun di dalam bahasan ini kita berfokus ada cara pembelajaran mempengaruhi persepsi yang berbeda dari cara proses perseptual mempengaruhi pembelajaran.

Pembelajaran perseptual pada hakikatnya mengacu kapada semua bentuk modifikasi persepsi yang dianggap sebagai pembelajaran Ada empat bentuk yang penting dalam definisi ini; (1) pembelajaran merupakan proses penafsiran, maksudnya adalah bahwa ia bukan sesuatu yang dapat diobservasi secara langsung, (2) konsep pembelajaran berkaitan dengan penampilan (performance), dan tidak sama dengan performance itu sendiri, (3) konsep pembelajaran berkaitan dengan kondisi latihan, yang membantu kita 
130 Analisis terhadap Perhatian dan Belajar Perseptual dalam Aktivitas Belajar Siswa - Ilham Wahyudi, Neviyarni

DOI : https://doi.org/10.31004/edukatif.v3i1.231

membedakan antara pembelajaran dengan penampilan, (4) pembelajaran (learning) merupakan proses yang relatif permanen.

Secara sistematis, proses pembelajaran dapat dideskripsikan sebagai proses pengantara antara kondisi latihan dengan perubahan penampilan, seperti yang terlihat dibawah ini:

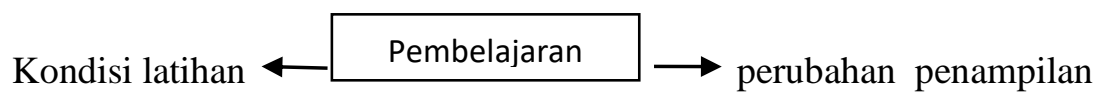

Tahap kondisi latihan mengacu kepada berbagai kondisi yang barangkali bervariasi pada beberapa setting eskperimen. Hal ini mencakup kondisi seperti sejumlah latihan, kondisi pemberian hadiah dan hukuman, pemberian balikan, latihan menyebar, mencari keamanan, dan kebermaknaan. Lebih lanjut Henry C Ellis (1978 : 210), menjelaskan bahwa persepsi merupakan suatu proses yang ditafsirkan dari perubahan penampilan yang disebabkan oleh kondisi stimulus. Dimana seperti dalam sebuah pembelajaran, persepsi merupakan proses penafsiran atau penghipotesisan yang berkaitan terhadap perubahan penampilan. Perbedaan yang prinsipil terletak pada hakikat kondisi awal (antecedent condition). Kondisi awal untuk persepsi adalah kondisi stimulus, sedangkan kondisi awal untuk pembelajaran adalah kondisi latihan (practice). Persepsi, seperti juga pembelajaran, merupakan konsep hubungan yang ditafsitkan dari perubahan penampilan maupun stimulus yang datang.

\section{Kategori Tugas-tugas Perseptual}

Henry C Ellis (1978 : 211) menjelaskan bahwa studi mengenai pembelajaran persepsi terfokus pada bagaimana kondisi praktik diproduksi dan diubah di dalam sebuah persepsi. Pembelajaran perseptual diklasifikasikan menjadi lima dasar respon, yaitu:

1. Pendeteksian (detection), merupakan tugas dimana pengamat melaporkan keberadaan dan tidak keberadaan sebuah stimulus. Hal ini hampir sama dengan saat mengangkat sebuah telepon, hal ini menandakan bahwa kita mendeteksi adanya stimulus yang datang.

2. Pembedaan (discrimination), misalnya seseorang yang bertugas untuk membedakan cita rasa dari dua jenis minuman keras. Walaupun tidak diberi tahu nama dan jenisnya, namun ia akan dapat membedakan kedua cita rasa tersebut dan mengemukakan bahwa dua benda tersebut benar-benar berbeda. Dengan kata lain discrimination disini yaitu laporan suatu perbedaan diantara dua stimulus.

3. Pengenalan (recognition), dalam suatu pengamatan seorang pengamat harus melaporkan apakah suatu tes stimulus tertentu itu sudah familiar atau tidak familiar, yang diikuti oleh suatu periode traning dimana pengamat melihat satu stimulus atau lebih.

4. Pengidentifikasi (identification), yaitu suatu tugas perseptual yang memerlukan pemberian respon yang unik untuk setiap stimulus.

5. Penilaian (Judgment), yaitu tugas respon perceptual mengacu kepada penempatan dan penyusunan stimulus dengan beberapa ukuran/skala.

\section{E. Hal-hal yang Dipelajari dalam Belajar Perseptual}

Menurut Henry C Ellis (1978 : 213), terdapat enam kategori kajian pembelajaran perseptual. Pertama adalah pengaruh latihan terhadap keterampilan perseptual. Keterampilan, perseptual meningkat sebagai akibat latihan. Secara umum peningkatan dalam semua tugas perseptual-detection, descrimination, recognition, 
131 Analisis terhadap Perhatian dan Belajar Perseptual dalam Aktivitas Belajar Siswa - Ilham Wahyudi, Neviyarni

DOI : https://doi.org/10.31004/edukatif.v3i1.231

identification, dan judgment- merupakan hasil dan latihan, seperti keterampilan menelusuri atau mencari sesuatu. Lama waktu melakukan penelusuran berkurang bila waktu latihan semakin lama. Peningkatan keterampilan perseptual berkorelasi secara negatif dengan lama waktu yang diperlukan untuk melakukan suatu tugas, semakin lama waktu latihan semakin sedikit waktu melaksanakan tugas perseptual.

Kategori kedua pembelajaran perseptual adalah faktor pemberian hadiah (reward) dan hukuman (punishment). Di bawah kondisi tertentu kita cenderung menerima stimulus yang telah diasosiasikan dengan hadiah (reward). Kategori ketiga dari pembelajaran perseptual ditinjau dari sudut waktu seseorang beradaptasi dengan stimulus yang ditransformasikan ke dalam beberapa bentuk yang berbeda (adaptation to transformed stimulation). Umpamanya, bila kita memakai kaca mata yang dirancang untuk melihat bumi dalam posisi terbalik, maka kita menemui masalah mengembalikan persepsi tentang bumi tadi. Bumi tidak mengalami perubahan, tetapi persepsi kita tentang bumi itu sendiri yang telah mengalami perubahan. Pada saat itu semuanya tetap seperti semula, tetapi kita harus belajar untuk mengreorientasikan diri kita sendiri dengan stimulus yang baru ini.

Dengan demikian, manusia memerlukan waktu untuk beradaptasi dengan stimulus yang telah ditransformasikan. Keempat adalah kajian yang berkaitan dengan cross-modal transfer, mengacu kepada kenyataan bahwa pembelajaran di dalam satu sistem pengindraan seperti model visual dapat beralih ke sistem pengindraan yang lain seperti model tektual (textual mode). Umpamanya, bila anda mempelajari tugas yang berisi stimulus yang berpola visual, kemudian pembelajaran tersebut akan beralih kepada tugas kedua jika stimulus tersebut diberikan dalam bentuk tekstual. Pada tugas pembelajaran kedua hanya melihat stimulus tekstual, kemudian kita hanya merasakan stimulus visual. Hal ini mengacu kepada teori persepsi yang disebut dengan keterpaduan indra (unity of the sense).

Kategori kelima dari kajian pembelajaran perseptual adalah peranan verbal labels dalam pembelajaran perseptual. Bahasa atau label-label verbal dapat membantu manusia membedakan sesuatu yang membingungkan atau yang sangat mirip. Jika label verbal yang berbeda diasosiasikan dengan stimulus yang membingungkan, proses ini akan membantu membuat stimulus tersebut lebih jelas dan tidak membingungkan. Pengaruh ini jelas sangat terlihat pada saat kita menghubungkan kerumitan sebuah stimulus dengan sesuatu yang dapat dikodekan dengan bentuk. Pola visual yang kompleks lebih sulit dikodekan secara verbal, dan jika subjek diberikan label verbal yang representatif dengan bentuk tersebut. Maka label tersebut akan membantu orang untuk meng-encode (membuat kode) pola tersebut lebih efisien dan lebih cepat. Sebaliknya, bila bentuk tersebut sederhana dan mudah di-encode, maka asosiasi label verbal tidak cenderung memberikan banyak bantuan pada apa yang dapat dilakukan.

Penelitian lain yang berhubungan dengan pengaruh pelabelan verbal adalah penelitian yang mengacu pada istilah yang disebut dengan acquivalence of cues (kesamaan kunci yang diterima). Secara umum, stimulus menjadi lebih sulit untuk diingat bila label yang sudah biasa diberikan pada stimulus tersebut. Jadi label verbal tidak hanya membantu penampilan perseptual, tetapi mereka juga membantu mengubah cara manusia merespon stimulus tersebut.

Kategori terakhir adalah scema learning (pembelajaran skema). Skema merupakan sebuah konsep yang dikembangkan dari pengkajian serangkaian stimulus yang mirip atau saling berkaitan. Skema mewakili beberapa kecenderungan sentral stimulus yang dibentuk terhadap yang sudah dieksposkan. Dalam hal ini skema lebih kurang seperti sebuah bentuk yang dapat mewakili beberapa gambar visual dari anggota peristiwa tertentu. Sehingga kita akan mempunyai skema untuk berbagai bentuk seperti pohon, rumah, orang, wajah, mobil, buku dan lain-lain. Jadi, skema pada dasarnya merupakan konsep yang ditafsirkan berdasarkan respon yang dikelompok-kelompokkan. Namun bagi, Selby Evan dan Michael Posner, mendefinisikan skema dalam bentuk kemajuan eksperimen ketimbang penafsiran keberadaannya. 
132 Analisis terhadap Perhatian dan Belajar Perseptual dalam Aktivitas Belajar Siswa - Ilham Wahyudi, Neviyarni

DOI : https://doi.org/10.31004/edukatif.v3i1.231

Menurut Eleanor Gibson (dalam Henry C Ellis, 1978 : 218-219) menjelaskan bahwa terdapat tiga aspek yang dipelajari di dalam pembelajaran perseptual:

1. Peningkatan di dalam pengkhususan pemberian respon. Pembelajaran perseptual bukanlah pembelajaran respon dari perseorangan akan tetapi akan dilihat dari tanggapan-tanggapan variabel stimulasi yang sebelumnya tidak mendapat tanggapan.

2. Pendeteksian dalam bentuk yang berbeda. Akhirnya berhubungan dengan proses pertama seperti yang dikatakan oleh Gibson mengenai pendeteksian ciri-ciri khusus. Seperti belajar membandingkan, yaitu untuk membedakan perbedaan antara sepasang kucing kembar. Pada sentuhan pertama mereka kesulitan untuk membedakan dasar karakter tunggal. Dalam hal itu banyak stimulus yang beranekaragam harus dibedakan atas dasar sekumpulan karakteristik yang lebih dari sekedar sendiri.

3. Pendeteksian property dan pola. Gibson telah mengusulkan bahwa pendeteksian pengaturan adalah aspek dari pembelajaran perseptual. Dibandingkan dengan contoh sebelumnya dari mengenali suatu nada dimana nada itu dimainkan. Ada suatu event yang mendeteksi suatu pola teladan atau keteraturan di dalam rangsangan. lebih umum lagi, proses ini melibatkan pendeteksian property untuk menentukan rangsangan.

\section{F. Implikasi-impikasi Praktis}

Menurut Henry C Ellis (1978 : 219), kajian tentang pembelajaran perseptual berfokus pada properti stimuli dalam sebuah tugas pembelajaran. Dalam stimuli, terletak penekanan terhadap stimulus yang kompleks dimana pada awal stimulus yang ada terdapat perbedaan peranan dari karakteristik struktural dan stimulus yang ada dalam sebuah pembelajaran. Aplikasi dari teori ini dikemukakan oleh Eleanor Gibson dalam penerapannya terhadap keterampilan membaca, diantara tahap tersebut adalah:

1. Berlangsung selama beberapa tahun yaitu tahap belajar berbicara.

2. Peserta didik belajar membedakan huruf yang tercetak, karena hal tersebut merupakan unit terkecil dari sistem penulisan.

3. Tahap selanjutnya adalah proses pemecahan kode (decoding) huruf menjadi bunyi, yakni belajar mengkombinasikan huruf menjadi bunyi.

4. Tahapan dimana peserta didik/siswa harus mempelajari unit yang tersusun lebih rumit, seperti sebuah kata, frase dan kalimat.

\section{G. Perhatian dan Belajar Perseptual terhadap Aktivitas Belajar Siswa.}

Perhatian dan belajar perseptual merupakan sebuah metode atau langkah pengajaran dalam membentuk aktivitas belajar yang kondusif bagi peserta didik (siswa), dimana dengan perhatian membentuk pola dan tingkah perilaku peserta didik untuk tetap fokus. Perhatian merupakan sebuah sikap atau perilaku yang dilakukan secara sadar dan sengaja dengan tujuan untuk mendapatkan informasi secara utuh dan maksimal. Sedangkan belajar perseptual adalah perubahan perilaku dari pembelajaran yang didapat siswa dengan arah yang lebih baik atau ke arah tujuan standar pendidikan yang telah ditetapkan.

Dalam proses pembelajaran, perhatian dan belajar perseptual merupakan sebuah usaha yang dilakukan dalam membentuk siswa agar aktif dan efektif dalam pembelajaran dengan berbagai bahasan terkait dengan perhatian dan belajar perseptual. 
133 Analisis terhadap Perhatian dan Belajar Perseptual dalam Aktivitas Belajar Siswa - Ilham Wahyudi, Neviyarni

DOI : https://doi.org/10.31004/edukatif.v3i1.231

Perhatian dan belajar perseptual memiliki perannya tersendiri dalam membentuk pola perilaku siswa dalam menerima pembelajaran, dimana perhatian dan belajar perseptual merupakan bentuk sarana pendukung individu dalam menerima dan memproses rangsangan stimulus yang diberikan guru ketika pembelajaran berlangsung.

\section{H. Aktivitas Belajar pada Siswa}

Pengertian aktivitas belajar pembelajaran yang efektif adalah pembelajaran yang menyediakan kesempatan belajar sendiri atau melakukan aktivitas sendiri. Proses pembelajaran yang dilakukan di dalam kelas merupakan aktivitas mentransformasikan pengetahuan, sikap, dan keterampilan (Martinis Yamin, 2007: 75). Aktivitas merupakan prinsip atau asas yang sangat penting dalam interaksi belajar mengajar (Sardiman, 2006: 96). Saat pembelajaran berlangsung siswa mampu memberikan umpan balik terhadap guru.

Sardiman (2006: 100) menyatakan bahwa aktivitas belajar merupakan aktivitas yang bersifat fisik maupun mental. Dalam kegiatan belajar, keduanya saling berkaitan. Oemar Hamalik (2009: 179) menyatakan bahwa aktivitas belajar merupakan kegiatan yang dilakukan oleh siswa dalam kegiatan pembelajaran. Aktivitas belajar dapat terwujud apabila siswa terlibat belajar secara aktif. Martinis Yamin (2007: 82) mendefinisikan belajar aktif sebagai usaha manusia untuk membangun pengetahuan dalam dirinya. Pembelajaran akan menghasilkan suatu 10 perubahan dan peningkatan kemampuan, pengetahuan dan ketrampilan pada diri siswa. Siswa mampu menggali kemampuannya dengan rasa ingin tahunya sehingga interaksi yang terjadi akan menjadi pengalaman dan keinginan untuk mengetahui sesuatu yang baru.

Berdasarkan pendapat di atas, dapat disimpulkan bahwa aktivitas belajar merupakan kegiatan atau tindakan baik fisik maupun mental yang dilakukan oleh individu untuk membangun pengetahuan dan keterampilan dalam diri dalam kegiatan pembelajaran. Aktivitas belajar akan menjadikan pembelajaran yang efektif. Guru tidak hanya menyampaikan pengetahuan dan keterampilan saja. Namun, guru harus mampu membawa siswa untuk aktif dalam belajar.

\section{KESIMPULAN}

Perhatian dan belajar perseptual dalam aktivitas belajar siswa merupakan sebuah metode pembelajaran yang dapat mendukung proses belajar mengajar supaya efektif dan juga merupakan langkah dalam mencapai tujuan pembelajaran.

Pada perhatian dan belajar perseptual merupakan wadah atau metode yang menjebatani beberapa unsur dari tujuan pembelajaran, tujuan pembelajaran merupakan sebuah arah yang ingin dituju dari rangkaian aktivitas yang dilakukan dalam proses pembelajaran. Hal tersebut dirumuskan dalam bentuk perilaku kompetensi spesifik pada siswa, aktual, dan terukur sesuai yang diharapkan terjadi, dimiliki, atau dikuasai siswa setelah mengikuti kegiatan pembelajaran tertentu.

Jadi, perhatian dan belajar perseptual pada siswa mempunyai peran dalam menunjang aktivitas belajar siswa. Dengan penerapan metode dan teori yang mendasari perhatian dan belajar perseptual, memberi dampak terhadap aktivitas belajar siswa dalam bentuk perhatian dan persepsi yang baik terhadap rangsangan stimulus yang diberikan kepada siswa dalam proses belajar mengajar. Sehingga pembelajaran yang dikehendaki dapat berjalan sesuai dengan tujuan pembelajaran.

\section{DAFTAR PUSTAKA}

Abu Ahmadi. (2003). Psikologi Umum. Jakarta: Rineka Cipta. 
134 Analisis terhadap Perhatian dan Belajar Perseptual dalam Aktivitas Belajar Siswa - Ilham Wahyudi, Neviyarni

DOI : https://doi.org/10.31004/edukatif.v3i1.231

Bimo Walgito. (2010). Pengantar Psikologi Umum. Yogyakarta: Andi Offset.

Daryanto.(2010). Belajar dan Mengajar. Bandung: CV. YRAMA WIDYA.

Henry C Ellis. (1978). Fundamentals of Human Learning.Memory and CognitionMichael Domjan. 2010. The Principles of Learning and Behavior, 6th Edition. California: Wadsworth.

Kevin Connolly. 2014.Perceptual Learning and the Contents of Perception1.79:1407-1418 DOI 10.1007/s10670-014-9608-y. Received: 2 July 2013 / Accepted: 6 February 2014 / Published online: 18 February 2014 Springer Science+Business Media Dordrecht 2014

N. J. Mackintosh. 2009. Varieties of perceptual learning.2009, 37 (2), 119-125 doi:10.3758/LB.37.2.119

Sarlito W. Sarwono. (2009). Pengantar Psikologi Umum. Jakarta: PT RajaGrafindo Persada.

Valtteri Arstila. 2016. erceptual Learning Explains Two Candidates for Cognitive Penetration. 81:1151-1172 DOI 10.1007/s10670-015-9785-3

Wissal Belhaj Rhouma. 2016. PERCEPTUAL LEARNING STYLES PREFERENCES AND

ACADEMIC ACHIEVEMENT. CD-ROM. ISSN: 1944-6934 :: 09(02):479-492. 